\title{
CrimRxiv
}

\section{Planning for Crime Prevention:A Transatlantic Perspective}

Ted Kitchen, Richard H Schneider

Published on: Oct 25, 2001

DOI: $10.21428 / c b 6 a b 371.07 c 2165 b$

License: Creative Commons Attribution 4.0 International License(CC-BY 4.0). 
